Simionescu Mihaela,

PhD, Senior Researcher at the Institute of Economic Forecasting, Romanian Academy (Bucharest, Romania);

Strielkowski Wadim,

PhD, Research Associate of Cambridge Judge Business School, University of Cambridge (Cambridge, United Kingdom)

\title{
BRAND LOYALTY AND FASHION MARKETING: A CASE STUDY OF ROMANIAN YOUTH
}

Our paper tackles a novel issue of brand loyalty withing the realm of fashion marketing. Fashion marketing represent a very creative, innovative and rapidly growing field with the earnings randing in billions of dollars each year. We analyze the patterns and the choice of brands using the empirical analysis of the attitude and loyalty to a brand of a group of young Romanians aged between 18-30 years. Our sample includes 200 people who took part in the consumer survey. Our results show that the main determinants of selecting certain brands are reason and value as well as the social status. It appears that education has a negative outcome on brand loyalty and the higher personal income increases the probability of going for the brand.

Keywords: brand loyalty, consumer preferences, fashion marketing, principal component analysis, consumer survey.

DOI: 10.21272/mmi.2017.1-02

Introduction. Consumption behaviour and the consumers' choices and preferences for particular brands are influenced by a plethora of various factors and indications including consumers' demographics, their culture, political factors, consumers' faith, social factors as well as environment [1]. Customer loyalty to brands represents one of the key assets of any enterprise and it is very important in keeping and enlarging the customers' base. Brands constitute a key element in creating the enterprise name and position on the market, as well as a reference point for its clients [2].

The significance of customer loyalty becomes even more important for the growth and survivial of any enterprise in the situation when the relevant market becomes saturated and no new customers are in sight [3]. Another factor that helps the companies to retain their customers might be through a considerable segmentation of the market where none of the main players possesses more than $16 \%$ of market share.

Analysis of recent research and publications. Many factors play role in influencing consumption behaviour including consumers' demographics, their culture, political factors, consumers' faith, social factors as well as environment [1] For example, Dick and Basu [4] described customer loyalty as "a relationship between relative attitude and repeat patronage". Salegna and Fazel [5] defined brand loyalty as "commitment, behavioural intent and behaviour to repurchase a particular brand".

Consumer behavior and consumer loyalty is subjected to several theoretical approaches [6-9]. For instance, Solgaard and Hansen [10] came up with the model of consumer choice based on consumer perceived utility (i.e. the consumer's perception of what she or he gives and receives). The receiving part can be described by store's service output [11]. The giving part is represented by the cost of purchased goods and services which can be expressed in terms of time and money spent in the process of shopping [12]. It can be shown that the rational behavior (i.e. when one assumes all consumers to be rational economic agents) makes consumers to shop in the stores with greatest output for the money spent [13]

Furthermore, Gounaris and Stathakopoulos [14] argued that brand loyalty has been viewed from three dimensions; a behavioural dimension demonstrated by repeated purchases, an attitudinal dimension manifested by preference, commitment or intention to purchase and a reasoned action dimension affected by social influences that can be derived from many factors such cultural, religious or political factors. 
Another pattern in the marketing literature is referring to the consumer shop choice and consumer loyalty as not only immediate cost-benefit analysis, but as the long-term concept of customer-based brand equity leading to customer loyalty.

It becomes apparent that successful branding can transform into the emotional commitment, shopping loyalty, and even person-to-person promotion of the brand to others over time. All of the above is true for all kinds of brands but our purpose here is to concentrate on fashion marketing and fashion brands, in particular eliciting preferences for these brands and determining the drivers of the consumers' consumption and choices.

The diversity of findings from the existing economic literature indicates the heterogeneity marking this cohort. There are few age structures based on social and ethnic diversity, buying behaviour or employment [15]. Most papers regarding fashion clothing cover either the entire cohort [16] or specific segments regarding students or tax-payers [17-21]. These studies focused on purchasing motivation, information sources, willingness-to-pay, willingness-to-accept, or eliciting consumer preferences.

The main objective of paper is to investigate the consumer preferences and choices for the popular fashion brands using a sample of young people aged between 18 and 30 years. Moreover, we want to understand the main motivations and determinants of consumer loyalty and brand loyalty. We employ empirical analysis and statistical models and tools to achieve these goals.

Basic materials. The aim of was to to provide an empirical analysis of the attitude and loyalty to a brand of a group of young Romanians aged between 18-30 years. Our sample included 200 people of these ages that were the object of a questionnaire survey organized in 2016 in a private university in Bucharest among its students. A principal analysis was conducted to identify some patterns in their choices for brands.

The principal components method replaces the initial variables $x^{1}, x^{2}, \ldots, x^{p}(p-$ number of initial variables), that are correlated, with the new characteristics (called principal components) and denoted as, $c^{1}, c^{2}, \ldots$ which represent linear combinations of the initial variables with the following properties:

- the principal components suppose maximal variance;

- the principal components are not inter-correlated;

The principal components are correlated with the initial variables, in order to keep as much information as possible.

Empirical model. In order to achieve our objectives, we run several statistical models based on the principal components analysis. Table 1 that follows shows the results of the principal analysis pattern in the choices for selected brands.

Table 1 - Brands from the same product category bought in the last year (own results)

\begin{tabular}{|l|r|r|}
\hline \multicolumn{3}{|c|}{ Communalities } \\
\hline & Initial & Extraction \\
\hline Bought from online stores & 1,000 &, 553 \\
\hline Frequency of buying clothes & 1,000 &, 670 \\
\hline Money spent on clothes each year & 1,000 &, 587 \\
\hline The clothes seen before to relatives/friends & 1,000 &, 546 \\
\hline In-store product comparisons & 1,000 &, 586 \\
\hline Desire of a new item & 1,000 &, 591 \\
\hline Seasonal wardrobe renewal & 1,000 &, 531 \\
\hline Matching with another item & 1,000 &, 613 \\
\hline Manufacturing (cuting, printing, labeling, etc.) & 1,000 &, 619 \\
\hline Salary & 1,000 &, 630 \\
\hline Gender & 1,000 &, 457 \\
\hline Level of education & 1,000 &, 720 \\
\hline Extraction Method: Principal Component Analysis \\
\hline
\end{tabular}


We are interested to have communalities that are close to 1 . This indicates that the model explains most of the variation of the initial characteristics. In our case, the empirical model expain better the variation in: manufacturing, salary, matching with another product.

Table 2 - Results of the principal analysis patterns: choices for brands (own results)

\begin{tabular}{|c|r|r|r|r|r|r|}
\hline \multicolumn{7}{|c|}{ Total Variance Explained } \\
\hline \multirow{2}{*}{ Component } & \multicolumn{7}{|c|}{ Initial Eigenvalues } & \multicolumn{2}{c|}{ Extraction Sums of Squared Loadings } \\
\cline { 2 - 7 } & \multicolumn{1}{|c|}{ Total } & $\%$ of variance & Cumulative, \% & \multicolumn{1}{c|}{ Total } & \% of variance & \multicolumn{1}{c|}{ Cumulative, \% } \\
\hline 1 & 1,945 & 16,206 & 16,206 & 1,945 & 16,206 & 16,206 \\
\hline 2 & 1,663 & 13,855 & 30,061 & 1,663 & 13,855 & 30,061 \\
\hline 3 & 1,258 & 10,480 & 40,541 & 1,258 & 10,480 & 40,541 \\
\hline 4 & 1,222 & 10,180 & 50,722 & 1,222 & 10,180 & 50,722 \\
\hline 5 & 1,017 & 8,478 & 59,200 & 1,017 & 8,478 & 59,200 \\
\hline 6 &, 888 & 7,397 & 66,597 & & & \\
\hline 7 &, 857 & 7,142 & 73,739 & & & \\
\hline 8 &, 760 & 6,332 & 80,071 & & & \\
\hline 9 &, 719 & 5,989 & 86,061 & & & \\
\hline 10 &, 589 & 4,906 & 90,967 & & & \\
\hline 11 &, 587 & 4,891 & 95,857 & & & \\
\hline 12 &, 497 & 4,143 & 100,000 & & & \\
\hline Extraction Method: Principal Component Analysis \\
\hline 78
\end{tabular}

There are 5 principal components that explain the attitude regarding a brand, in general. The results are reported in Table 3 that follows.

Table 3 - Results of the principal analysis patterns: choices for brands (own results)

\begin{tabular}{|c|c|c|c|c|c|}
\hline \multicolumn{6}{|c|}{ Component matrixa } \\
\hline & \multicolumn{5}{|c|}{ Component } \\
\hline & 1 & 2 & 3 & 4 & 5 \\
\hline Bought from Online stores & -332 & ,286 &,- 161 &,- 575 & 068 \\
\hline Frequency of buying clothes & ,407 & ,301 &,- 494 &,- 388 &,- 139 \\
\hline Money spent on clothes each year &,- 468 & ,248 & ,386 & ,370 & 144 \\
\hline $\begin{array}{l}\text { The clothes seen before to } \\
\text { relatives/friends }\end{array}$ & -397 &,- 024 &,- 440 & ,422 & 131 \\
\hline In-store product comparisons & ,183 &,- 343 &, 520 & -398 &,- 086 \\
\hline Desire of a new item & ,527 & ,234 & -143 & ,281 & ,398 \\
\hline Seasonal wardrobe renewal & ,537 &,- 244 &,- 156 & ,284 &,- 279 \\
\hline Matching with another item & ,460 & ,049 & ,424 &,- 103 & ,456 \\
\hline $\begin{array}{l}\text { Manufacturing (cuting, printing, labeling } \\
\text { etc) }\end{array}$ & ,521 & 164 & 238 & ,302 &,- 416 \\
\hline Salary &,- 090 & ,749 & ,224 & ,048 & ,091 \\
\hline Gender &,- 434 &,- 422 & ,148 & 056 &,- 256 \\
\hline Level of education & ,114 &,- 655 &,- 147 &,- 016 &, 506 \\
\hline \multicolumn{6}{|c|}{ Extraction Method: Principal Component Analysis } \\
\hline a. 5 components extracted & & & & & \\
\hline
\end{tabular}

Looking at the results reported in Tables 2 and 3 , one can see that there are 4 principal components that explain the frequency a person buys clothes of the same brand of the last 10 purchases in Romania:

- reason and value (PC1- principal component 1) which is a linear combination of the following 
variables: seasonal wardrobe renewal, and manufacturing (this is the most important principal component which explains $16.206 \%$ of the persons' loyalty for a brand): PC1 $=0.537 \times$ seasonal wardrobe renewal $+0.521 \times$ manufacturing;

- social status (PC2) which is a linear combination of two variables: wage and highest graduated education level. This principal component explains $13.855 \%$ of the loyalty: $P C 2=0.749 x$ wage $-0.655 x$ education. Young people with higher salary can afford to be more loyal to a brand, while higher the education is, lower is the loyalty to brand;

- the third principal component (PC3)- source of information which explains $10.48 \%$ of the fidelity to buy clothes of the same brand in the last year is represented by in-store product comparisons that had a positive impact: PC3= 0.52x in-store product comparisons. Because of the low outcome, the young people tend to compare the traditional stores with different products;

- moreove, it appears that the availability of the Internet (PC4) explains $10.18 \%$ of the loyalty for a brand in the last year, but it has a negative impact: PC4= $-0.575 \times$ on-line stores. Table 4 that follows depicts the analysis of frequency of the repetitive buying of clothes of the same brand.

\section{Table 4 - Frequency of buying clothes of the same brand (own results)}

\begin{tabular}{|l|r|r|}
\hline \multicolumn{3}{|c|}{ Communalities } \\
\hline & \multicolumn{1}{|c|}{ Initial } & \multicolumn{1}{c|}{ Extraction } \\
\hline Manufacturing (cuting, printing, labeling etc) & 1,000 &, 761 \\
\hline Stores with several brands & 1,000 &, 803 \\
\hline Stores with only one brand & 1,000 &, 711 \\
\hline Stores with clothes below a certain price level & 1,000 &, 559 \\
\hline Leisure & 1,000 &, 420 \\
\hline Brand reputation & 1,000 &, 726 \\
\hline Fabric & 1,000 &, 750 \\
\hline Scholarship & 1,000 &, 683 \\
\hline Extraction Method: Principal Component Analysis & & \\
\hline
\end{tabular}

Table 5 - Total variance, buying clothes of the same brand (own results)

\begin{tabular}{|c|c|c|c|c|c|c|}
\hline \multicolumn{7}{|c|}{ Total Variance Explained } \\
\hline \multirow{2}{*}{ Component } & \multicolumn{3}{|c|}{ Initial Eigenvalues } & \multicolumn{3}{|c|}{ Extraction Sums of Squared Loadings } \\
\hline & Total & $\%$ of variance & Cumulative, $\%$ & Total & $\%$ of variance & Cumulative, $\%$ \\
\hline 1 & 1,687 & 21,082 & 21,082 & 1,687 & 21,082 & 21,082 \\
\hline 2 & 1,401 & 17,512 & 38,594 & 1,401 & 17,512 & 38,594 \\
\hline 3 & 1,286 & 16,077 & 54,671 & 1,286 & 16,077 & 54,671 \\
\hline 4 & 1,039 & 12,993 & 67,663 & 1,039 & 12,993 & 67,663 \\
\hline 5 &, 871 & 10,885 & 78,548 & & & \\
\hline 6 & 776 & 9,701 & 88,249 & & & \\
\hline 7 &, 532 & 6,652 & 94,901 & & & \\
\hline 8 & 408 & 5,099 & 100,000 & & & \\
\hline \multicolumn{7}{|c|}{ Extraction Method: Principal Component Analysis } \\
\hline
\end{tabular}

The principal component analysis was applied to select some factors that might affect the loyalty to a certain brand (Table 6).

One has to note that in Table 6 we only selected the principal components for which eigenvalues are greater than 1. Our results show that there are 4 principal components that explain how often a person buys clothes of the same brand in Romania. 
Table 6 - Component matrix, buying clothes of the same brand (own results)

\begin{tabular}{|l|r|r|r|r|}
\hline \multicolumn{5}{|c|}{ Component matrix ${ }^{\mathbf{y}}$} \\
\hline & \multicolumn{5}{|c|}{ Component } \\
\cline { 2 - 5 } & 1 & 2 & 3 & 4 \\
\hline Manufacturing (cuting, printing, labeling etc) &, 833 &, 180 &, 073 &,- 173 \\
\hline Stores with several brands &,- 167 &, 690 &, 051 &,- 545 \\
\hline Stores with only one brand &, 465 &,- 644 &,- 205 &,- 195 \\
\hline Stores with clothes below a certain price level &,- 224 &,- 230 &, 663 &, 128 \\
\hline Leisure &, 255 &, 575 &,- 103 &, 121 \\
\hline Brand reputation &, 308 &, 154 &,- 579 &, 521 \\
\hline Fabric &, 723 &,- 021 &, 458 &,- 135 \\
\hline Scholarship &, 133 &, 266 &, 491 &, 594 \\
\hline Extraction Method: Principal Component Analysis & \multicolumn{5}{|c|}{} \\
\hline a. 4 components extracted & \multicolumn{5}{|l|}{} \\
\hline
\end{tabular}

The results can be explained in the following way:

- provider and value (PC5) which is a linear combination of the following variables: manufacturing and fabric (this is the most important principal component which explains $21,082 \%$ of the persons' intention to buy clothes of the same brand): $P C 5=0,833 \times$ manufacturing $+0,723 \times$ fabric;

- the most important factor for this principal component is the manufacturing (this factor has the highest coefficient, namely 0,833 );

- shop and fun (PC6) which is a linear combination of 3 variables: stores with one brand, stores with several brands and leisure. This principal component explains $17,512 \%$ of the intention to buy clothes of the same brand: PC6 $=0,690 \times$ stores with several brands $-0,644 \times$ stores with one brand $+0,575$ x leisure;

- the stores with only one brand had a negative and strong influence on intention. Young people prefer going to shops with several brands rather than choosing a more specific shop with only one brand;

- store and brand reputation (PC7) which is a linear combination of 2 variables: stores with items below a certain price level and brand reputation. This principal component explains $16,077 \%$ of the intention to buy clothes of the same brand: $P C 6=0,6963 \times$ stores with items below a certain price level $0,579 \times$ brand reputation;

- these people prefer stores with items below a certain price level but the brand reputation is not taken into consideration in selecting a certain brand;

- scholarship (PC8) explains 12,993\% of intention to buy clothes of a certain brand. Young people who have a scholarship can afford to buy more clothes of a certain brand.

Overall, it appears that in the sample of the young people from Romania who were all students of a private university, some patherns regarding the reasons for a brand and the frequency of buying things of the same brand could be identified. It appears that the main reason for chosing a brand is related to seasonal wardrobe renewal and manufacturing. The high frequency of buying products of the same brand could be explained by manufacturing.

Conclusion and directions for further research. Our results demonstrate how brand loyalty and the willingness to pay for the loved brands might help the companies to tie up and to retain its customers.

The outcomes of the principal component analysis in the empirical part of the paper show that the reasons for the loyality to a certain brad are related to seasonal wardrobe renewal and manufacturing. The wage has a positive impact on a decision to be loyal to a certain brand. Contrary to our expectations, people with higher education are more interested in diversity than to follow a certain brand. The source of information regarding brands is reflected by the comparisons of traditional stores. 
The availability of Internet did not act like a factor that promoted the favoured specific brand. Moreover, the frequency of buying products of the same brand can be explained by several factors: the selection of shops with several brands and those with prices below a certain level, as well as the existence of a scholarship. Typically, the profile of young consumers who often buys clothes of the same brand reflects a young person who visits shops selling clothes from multiple brands or with lower expected prices and who, in most cases, has a scholarship. Manufacturing and fabric tend to be the most important factor that influences the frequency of buying clothes of the same brand.

Our results might be of help for major fashion brands and the new fashion start-ups that are starting to build their marketing strategy on the competigive markets.

As for the directions for further research, it seems that a more segmented analysis embracing the youth from several Central and Eastern European countries, or comparing the samples of respondents from the "new" and "old" EU countries might be very helpful in learing how different nations perceive brand loyalty and how they react to the marketing strategies that are tartgeted at promoting the brands.

1. Al-Hyari, K., Alnsour, M., Al-Weshah, G., \& Haffar, M. (2012). Religious beliefs and consumer behaviour: from loyalty to boycotts. Journal of Islamic Marketing, 3(2), 155-174 [in English].

2. Abrhám, J., Bilan, Y., Krauchenia, A., \& Strielkowski, W. (2015). Planning horizon in labour supply of Belarusian small entrepreneurs. Economic Research-Ekonomska Istraživanja, 28(1), 773-787 [in English].

3. Ocampo, L.A., \& Estanislao-Clark, E. (2014). Developing a framework for sustainable manufacturing strategies selection. DLSU Business \& Economics Review, 23(2), 115-131 [in English].

4. Dick, A.S., \& Basu, K. (1994). Customer loyalty: Toward an integrated conceptual framework. Journal of The Academy of Marketing Science, 22(2), 99-113 [in English].

5. Salegna, G.J, \& Fazel, F. (2011). An examination of the relationships and interactions among product, brand, personal and service provider loyalty. Journal of Consumer Satisfaction, Dissatisfaction and Complaining Behavior, 24, $42-55$ [in English].

6. Piankova, O. (2014). Food and Beverage Brand Development: Global Trends and Directions for Ukraine, Economics \& Sociology, 7(2), 149-159 [in English].

7. Č́ábelková, I., Pogorilyak, B., Strielkowski, W., \& Stř́teský, V. (2015). Customer Store Loyalty Determinants: A Case of the Czech Republic, DLSU Business \& Economics Review, 25(1), 28-44 [in English].

8. Kola-Bezka M., Czupich M., \& Ignasiak-Szulc A. (2016). Smart cities in Central and Eastern Europe: viable future or unfulfilled dream? Journal of International Studies, 9(1), 76-87 [in English].

9. Čábelková, I., Strielkowski, W., \& Mirvald, M. (2015). Business influence on the mass media: a case study of 21 countries. Transformation in Business \& Economics, 14(1), 65-75 [in English].

10. Solgaard, H.S., \& Hansen, T. (2003). A hierarchical Bayes model of choice between supermarket formats, Journal of Retailing and Consumer Services, 10(3), 169-180 [in English].

11. Bucklin, L.P.; Ramaswamy, V.; \& Majumdar, S.K. (1996). Analyzing channel structures of business markets via the structure-output paradigm, International Journal of Research in Marketing, 13(1), 73-87 [in English].

12. Blackwell, R.D., Miniard, P.W., \& Engel, J.F. (2001). Consumer behaviour. 9th edition. Forth Worth: Harcourt [in English].

13. Hansen, T. (2001). Quality in the marketplace: A theoretical and empirical investigation. European Management Journal, 19(2), 203-211 [in English].

14. Gounaris, S., \& Stathakopoulos, V. (2004). Antecedents and consequences of brand loyalty: An empirical study, Journal of Brand Management, 11(4), 283-306 [in English].

15. Kinley, T.R., Josiam, B.M., \& Lockett, F. (2010). Shopping behavior and the involvement construct. Journal of Fashion Marketing and Management: An International Journal, 14(4), 562-575 [in English].

16. Guillot-Soulez, C., \& Soulez, S. (2014). On the heterogeneity of Generation Y job preferences. Employee Relations, 36(4), 319-332 [in English].

17. Strielkowski, W., \& Čábelková, I. (2015). Religion, Culture, and Tax Evasion: Evidence from the Czech Republic. Religions, 6(2), 657-669 [in English].

18. Strielkowski, W., Tumanyan, Y., \& Kalyugina, S. (2016). Labour Market Inclusion of International Protection Applicants and Beneficiaries. Economics \& Sociology, 9(2), 293-302 [in English].

19. O'Cass, A., Jin Lee, W., \& Siahtiri, V. (2013). Can Islam and status consumption live together in the house of fashion clothing? Journal of Fashion Marketing and Management: An International Journal 17(4), 440-459 [in English].

20. Chiabai, A., Platt, S., \& Strielkowski, W. (2014). Eliciting users' preferences for cultural heritage and tourism-related eservices: a tale of three European cities. Tourism Economics, 20(2), 263-277 [in English].

21. Pentecost, R., \& Andrews, L. (2010). Fashion retailing and the bottom line: The effects of generational cohorts, gender, fashion fanship, attitudes and impulse buying on fashion expenditure. Journal of Retailing and Consumer Services, 17(1), 43-52 [in English]. 
M. Сіміонеску, PhD, ст. науковий співробітник Інституту економічного прогнозування, Румунська академія (м. Бухарест, Румунія);

B. Стрієлковські, PhD, науковий співробітник Кембриджської бізнес-школи, Кембриджський Університет (м. Кембридж, Великобританія)

Лояльність до бренда та маркетинг моди: дослідження на прикладі молоді Румунії

Стаття стосується дослідження лояльності до бренда у сфрері маркетингу моди. Маркетинг моди сьогодні $\epsilon$ інноваційною та швидко зростаючою сфрерою з прибутками у кілька мільярдів доларів щороку. Автори аналізують особливості вибору брендів, використовуючи емпіричний аналіз щодо відношення та лояльності до них з боку групи молоді Румунії у віці 18-30 років. Вибірка включала 200 чоловік, які взяли участь в опитуванні. Результати дослідження показали, що основними факторами, що визначають вибір певного бренда є додаткова інфоормація про бренд, його цінність та соціальний статус людини. Виявилося, що освіта негативно впливає на лояльність до бренда, а вищі доходи особи підвищують імовірність того, що людина придбає брендований товар.

Ключові слова: лояльність до бренда, споживчі переваги, маркетинг моди, аналіз основних компонент, опитування споживачів.

M. Симионеску, PhD, ст. научный сотрудник Института экономического прогнозирования, Румунская академия (г. Бухарест, Румуния);

B. Стриелковски, PhD, научный сотрудник Кембриджской бизнес-школы, Кембриджский Университет (г. Кембридж, Великобритания)

Лояльность к бренду и маркетинг моды: исследование на примере молодежи Румунии

Статья касается исследования лояльности к бренду в сфере маркетинга моды. Маркетинг моды сегодня является инновационной и быстро растущей сферой с прибылью в несколько мильярдов долларов каждый год. Авторы анализируют особенности выбора брендов, используя эмпирический анализ касаемо отношения и лояльности к ним со стороны группы молодежи из Румунии возрастом 18-30 лет. Выборка включала 200 человек, которые приняли участие в опросе. Результаты исследования показали, что основными факторами, которые определяют выбор бренда, являются дополнительная инсормация о нем, его ценность и социальный статус человека. Оказалось, что образование негативно влияет на формирование лояльности к бренду, а более высокие доходы человека повышают вероятность того, что потребитель купит брендированный товар.

Ключевые слова: лояльность к бренду, потребительские предпочтения, маркетинг моды, анализ основных компонентов, опрос потребителей.

Отримано 05.12.2016p. 